\title{
GOVERNANSI PUBLIK DALAM PENGELOLAAN BADAN USAHA MILIK DESA DI KABUPATEN BANYUMAS
}

\author{
PUBLIC GOVERNANCE IN THE MANAGEMENT OF VILLAGE OWNED ENTERPRISES \\ IN BANYUMAS
}

\author{
Shadu Satwika Wijaya*, Chamid Sutikno* \\ * Program Studi Administrasi Publik, Universitas Nahdlatul Ulama Purwokerto \\ Jln.Sultan Agung No 42 Karangklesem, Purwokerto, Indonesia 53144 \\ Email: ss.wijaya@unupurwokerto.ac.id \\ Diterima: 12 Oktober 2020, Direvisi: 27 Oktober 2020, Disetujui: 30 Nopember 2020
}

\begin{abstract}
ABSTRAK
Pengembangan potensi lokal menjadi aspek penting untuk meningkatkan daya saing lokal. Oleh karena itu, pembentukan Badan Usaha Milik Desa (BUMDes) merupakan salah satu model pemanfaatan kapasitas finansial desa untuk pemanfaatan potensi dan kebutuhan desa. Namun, dalam perjalananya penerapan BUMDes masih menemukan permasalahan dalam mencapai tujuan pemanfaatan potensi dan kebutuhan desa. Tujuan penelitian ini adalah menemukan pendekatan yang tepat dalam mendukung upaya peningkatkan kinerja BUMDes dalam mengelola potensi desa. Hasil penelitian menunjukkan bahwa pengelolaan BUMDes belum didasarkan pada analisis kebutuhan dan pemetaan potensi desa setempat. Pengelolaan BUMDes perlu diarahkan menuju optimalisasi peran stakeholders melalui pendekatan governance.
\end{abstract}

Kata Kunci: Pengelolaan BUMDes, Governansi Publik, Peningkatan Kinerja

\section{ABSTRACT}

Increasing local potential is an important aspect to improve local competitiveness. Therefore, the establishment of Village-Owned Enterprises (BUMDes) is one model of village financial capacity utilization to utilize the potential and needs of the village. However, in the course of its implementation the BUMDes still found problems in achieving the objectives of using the village's potential and needs. The purpose of this study is to find the right approach in supporting efforts to improve the performance of BUMDes in managing village potential. The results of the study show that the management of the BUMDes has not been based on the needs analysis and mapping of the potential of the local village. Management of BUMDes needs to be directed towards optimizing the role of stakeholders through a governance approach.

Keywords: Performance Improvement, Public Governance, Village Enterprise Management

\section{PENDAHULUAN}

Pengelolaan kekayaan dan potensi desa melalui Badan Usaha Milik Desa (BUMDes) juga telah dilakukan oleh sejumlah desa di Kabupaten Banyumas. Pada saat ini telah berdiri 88 BUMDes dari 301 desa di Kabupaten Banyumas (Laporan Pemerintah Kabupaten Banyumas 2016). Meskipun dari segi jumlah belum mencapai angka 50 persen, namun dengan dukungan kebijakan baik dari pemerintah daerah dan pemerintah desa maka potensi pembentukan BUMDes akan sangat besar. Namun, kinerja Badan Usaha Milik Desa (BUMDes) dalam pengelolaan kekayaan dan potensi desa sebagai upaya membangun ekonomi masyarakat desa pada kenyataan masih 
sulit dilakukan. Masalah utama yang dihadapi adalah belum kuatnya mekanisme pemetaan potensi dan kebutuhan desa, sehingga kinerja BUMDes dalam pengelolaan kekayaan dan potensi desa masih belum terarah dan terukur. Hasil penelitian terdahulu yang dilakukan oleh Kurniasih et al. (2017; 2019) dan Maab et al. (2018) menunjukkan bahwa dalan pengelolaannya, BUMDes belum memiliki mekanisme yang jelas dan komprehensif terkait pemetaan potensi dan kebutuhan desa. Di samping itu, hasil penelitian terhadulu tersebut juga menunjukkan belum adanya mekanisme keterlibatan masyarakat secara lebih luas dalam pengembilan keputusan. Artinya, peran stakeholders dalam pengelolaan BUMDes belum diberi ruang yang optimal.

Business Improvement merupakan suatu hal yang penting untuk diperhatikan di level pemerintah daerah (Morçöl and Wolf, 2010). Integrasi organisasi sektor swasta dan mekanisme pasar ke dalam proses pemerintahan dan pelayanan publik merupakan tren yang memiliki implikasi mendasar bagi administrasi publik (Newman and Gaffney, 2002). Kerjasama pemerintah dan sektor bisnis dapat membantu mengidentifikasi solusi terhadap masalah kebijakan yang kompleks dan memperbaiki keberhasilan implementasi kebijakan publik (Kim and Darnall, 2016).

Najmaei dan Sadeghinejad (2016) mengenalkan konsep model bisnis publik dan mengembangkan teori untuk proses pengembangan dan pengelolaan model bisnis publik. Dalam pandangannya mengembangkan dan mengelola model bisnis merupakan hal yang penting untuk dilakukan dalam organisasi publik sekalipun. Pengusaha publik menjalankan tugas ini dengan menggunakan sumber daya publik dan swasta, memanfaatkan sistem kelembagaan publik, dan mengembangkan kemampuan yang berbeda dimana model bisnis publik dikembangkan dan digunakan. Dalam pemenuhan pelayanan publik bagi masyarakat juga diperlukan inovasi business models (Morçöl \& Wolf, 2010). Pengelolaan model bisnis menjadi penting untuk memanfaatkan peluang publik (Najmaei and Sadeghinejad, 2016). Oleh karena itu perlu dibentuk suatu badan usaha masyarakat desa. Tidak ada definisi yang jelas tentang apa yang dimaksud dengan bisnis pedesaan atau badan usaha milik desa (Henry dan McElwee, 2014). Menurut Henry dan McElwee (2014) Gagasan tentang bisnis pedesaan atau badan usaha milik desa dapat ditinjau dengan karakteristik sebagai berikut: (1) Lokasi utamanya berada di pedesaan; (2) Mempekerjakan mereka yang berada dalam area specified travel to work; (3) Berkontribusi terhadap gross value-added (GVA) bagi desa setempat.

Liang (2006) mencatat beberapa hal tentang proses perkembangan terbaru dalam restrukturisasi dan tantangan utama dari badan usaha desa. Ia berpandangan bahwa pengembangan lebih lanjut perusahaan pedesaan harus berfokus pada sejumlah isu kebijakan, antara lain: (1) Mengutamakan nilai-nilai sektor privat (perusahaan swasta), (2) Meningkatkan struktur industri, mengembangkan industri pengolahan makanan agribisnis, (3) Meningkatkan kualitas dan merek, (4) mendorong konsentrasi bisnis di kota-kota dan (5) Mendorong kolaborasi ekonomi dan teknis regional. Dalam pandangan Liang (2006), badan usaha desa adalah driving force di belakang ekonomi pedesaan, yang dapat menjadi kekuatan ekonomi baru, menyediakan kesempatan kerja untuk tenaga kerja pedesaan, membantu meningkatkan pendapatan petani, promotor industri infrastruktur dan agribisnis dan sebagai kontributor urbanisasi dan integrasi ekonomi regional. 
Wang (2005) juga mencatat beberapa hal tentang proses perkembangan badan usaha desa. Dalam pandangannya, badan usaha desa memiliki karakteristik, antara lain: (1) Sebagai pelopor pembangunan pedesaan; (2) Sebagai pilihan hak milik atau kepemilikian perusahaan; (3) Sebagai bantuan bagi beban ketimpangan petani; (4) Sebagai tipe industrialisasi pedesaan. Lebih lanjut Wang (2005) mengemukakan bahwa badan usaha desa beroperasi di bawah konteks geografis, ekonomi dan politik yang sangat unik karena berada di wilayah pedesaan. Oleh karena itu, untuk menjamin keberlangsungannya diperlukan perhatian pada upaya diversifikasi kepemilikan, prioritas pada pengembangan organisasi dan teknologi harus menjadi prioritas utama, mengutamakan industri pengolahan makanan (agri-industri), penguatan pada kualitas dan merek, mobilisasi atau ekspansi usaha yang menjangkau wilayah perkotaan dan mendorong kerjasama ekonomi dan teknis tingkat regional (Liang, 2006). Najmaei dan Sadeghinejad (2016) juga mengungkapkan bahwa perusahaan publik adalah seperti perusahaan swasta yang memerlukan model bisnis untuk bertindak. Namun, karena perbedaan sifat peluang dan sumber daya antara bisnis sektor publik dan swasta, maka berbeda pula penyelenggaraan perusahaan publik dengan perusahaan swasta.

Perusahaan publik itu sendiri tergolong ke dalam profit maximizing businesses dan non-profit maximizing businesses known as social businesses. Terdapat perpedaan antara perusahaan dengan profit maximizing businesses model dan social businesses model (Sabatier et al., 2017; Yunus et al., 2010). Bahwa perusahaan milik lokal lebih cenderung menghasilkan tingkat keterlibatan publik yang tinggi dan penting untuk menopang kapasitas pemecahan masalah publik. Keterlibatan publik dan pemilik bisnis lokal dapat memberikan kerangka kerja dengan mengalihkan beban pemecahan masalah dari pemerintah ke pelaku swasta, masyarakat dan stakeholder lain untuk memecahkan masalah masyarakat (Clark and Record (2017).

Kemunculan paradigma reinventing government yang menghendaki sebuah pemerintahan yang berjalan seperti atau menerapkan nilai-nilai organisasi swasta (Osborn dan Plastrik, 1997). Tentu saja tinjauan terhadap persoalan tersebut diharapkan tetap didasari pada pemikiran tentang bagaimana mengelola kepentingan publik secara efisien, efektif, akuntabel dan berkeadilan sosial. Dalam mengkaji persoalan BUMDes penelitian ini menggunakan perspektif manajemen publik, karena dalam konsep manajemen publik menyangkut perencanaan, pengorganisasian, pengawasan dan juga mekanisme pertanggungjawaban. Artinya, peran stakeholders dalam mekanisme pengelolaan BUMDes menjadi bagian yang penting. Dalam mengatasi kekosongan peran stakeholders inilah, perlu adanya mekanisme yang mendorong pengelolaan BUMDes yang berbasis pada konsep governance. Public governance adalah cara dimana stakeholders saling berinteraksi dengan tujuan mempengaruhi hasil kebijakan publik (Bovaird et al., 2003). Stakeholders tersebut antara lain adalah warganegara, organisasi masyarakat, media massa, lembaga publik, politisi, organisasi nirlaba dan sebagainya. Mereka saling berinteraksi dalam pengelolaan organisasi publik untuk memenuhi berbagai kepentingan masyarakat.

Pada paradigma government, pemerintah memainkan peranan penting dalam mengendalikan masyarakat. Sedang dalam paradigma governance dimungkinkan keterlibatan banyak kelompok kepentingan yang secara langsung terlibat dalam 
perumusan dan pelaksanaan kebijakan publik (Klijn \& Koppenjan, 2015). Konsep governance memperhitung-kan seluruh aktor dan area kebijakan yang berada di luar "eksekutif inti" yang terlibat dalam proses pembuatan kebijakan (Cairney \& Cairney, 2016; Klijn \& Koppenjan, 2015). Governnace dalam hal ini merupakan konsep yang luas yang mewakili keseluruhan kualitas hubungan antara warga negara (swasta dan masyarakat umum) dan pemerintah yang memuat nilai-nilai responsivitas, efisiensi, kejujuran dan keadilan (Matheus \& Ribeiro, 2009). Oleh sebab itu, dengan pendekatan governance, maka kondisi kebutuhan desa dapat lebih tergambarkan dengan jelas. Dengan tergambarkannya kondisi kebutuhan dan potensi desa, maka arah pengembangan BUMDes menjadi jelas dan terukur yang pada giliranya dapat meningkatkan kinerja BUMDes dalam mengelola kebutuhan dan potensi desa.

Dengan demikian, rumusan masalah dalam penelitian ini antara lain: (1) Bagaimanakah model eksisting pengelolaan BUMDes di Kabupaten Banyumas?; (2) Bagaimanakah model governansi publik dalam pengelolaan BUMDes di Kabupaten Banyumas? Melihat fenomena di atas dan potensi dari pendirian BUMDes itu sendiri, maka tujuan penelitian ini antara lain: (1) Mengidentifikasi model existing pengelolaan BUMDes di Kabupaten Banyumas; (2) Mengembangkan model governansi publik dalam pengelolaan BUMDes di Kabupaten Banyumas.

\section{METODE}

Penelitian ini menggunakan pendekatan studi kasus. Metode ini digunakan untuk mengetahui dan mengeksplorasi meaning dari individu atau kelompok sosial dan permasalahan sosial (Creswell, 2013: 4). Informan kunci dalam penelitian ini, antara lain: pemerintah desa, penyelenggara BUMDes dan masyarakat desa di beberapa desa di Kabupaten Banyumas. Teknik analisis data dalam penelitian ini menggunakan interactive data analysis model (Milles, Huberman and Saldana, 2014).

Adapun sasaran dari penelitian ini adalah keseluruhan BUMDes yang yang tersebar di 301 desa yang ada di Kabupaten Banyumas yang berjumlah 88 BUMDes. Dari jumlah tersebut kemudian diambil 30 BUMDes untuk jadikan informan dalam penelitian ini (34 \%) yang dipilih dengan teknik purposive. Metode pengumpulan data menggunakan indepth interview, observasi dan analisis dokumen.

\section{HASIL DAN PEMBAHASAN}

Besarnya potensi pendirian keterlibatan stakeholders yang memadai, sehingga pengelolaan BUMDes cenderung tersentral pada pemerintah desa, khususnya Kepala Desa. Kinerja BUMDes tidak disusun berdasarkan rencana strategis yang berbasis pada kebutuhan dan potensi pengembangan desa. Sehingga, ukuran kinerja BUMDes menjadi tidak terstandar dan bersumber sepenuhnya pada preferensi Pemerintah Desa, khususnya Kepala desa. Hasil penelitian juga menunjukkan bahwa secara umum pengelola telah membuka informasi pengelolaan BUMDes kepada masyarakat, meskipun belum terlembaga secara baik, karena belum tersedianya sistem informasi khusus dan pemanfaatan media yang optimal. Transparansi pelaporan pengelolaan BUMDes kepada masyarakat desa lebih diselenggarakan dengan pendekatanpendekatan yang informal seperti forum "kumpulan warga". Fakta penelitian tersebut sejalan dengan pendapat (O’Doherty, 2017) yang memandang bahwa transparansi semakin penting dalam penyelenggaraan pemerintahan kontemporer. Dalam pandangannya transparansi 
perlu didorong sebagai pendekatan dalam penyelenggaraan organisasi publik. Transparansi dipandang penting karena memiliki manfaat dalam mengimbangi kompleksitas perilaku politik, adminis- tratif dan sosial (Chygryn et al., 2018; Grimmelikhuijsen \& Feeney, 2017). Berikut merupakan gambaran model eksisting pengelolaan BUMDes.

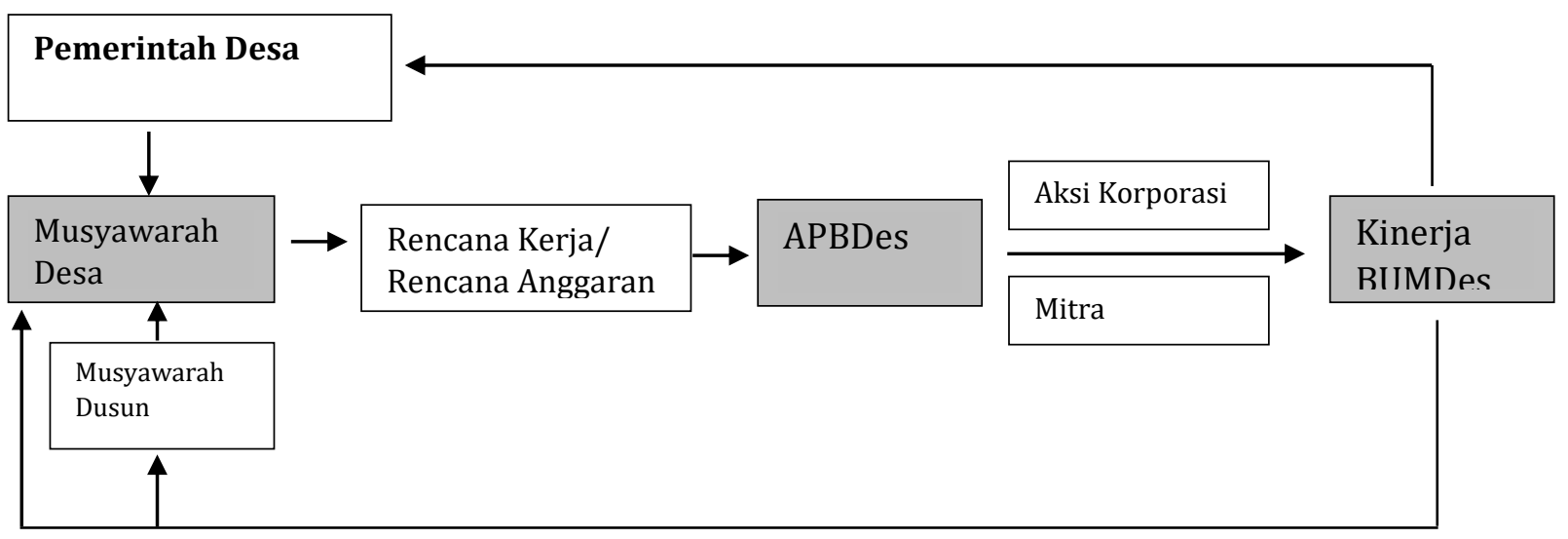

Gambar 1.

Model Eksisting Pengelolaan BUMDes

Gambar 1 di atas adalah model yang menggambarkan kondisi eksisting terkait dengan pola pengelolaan BUMDes, khususnya di Kabupaten Banyumas. Model eksisting tersebut dikembangkan berdasarkan hasil pengamatan dan wawancara mendalam dengan informan kunci. Melalui gambar model eksisting pengelolaan BUMDes tersebut dapat ditunjukkan bahwa terdapat peranan sentral dan dominasi pemerintah desa khususnya kepala desa dalam proses pengelolaan BUMDes. Fakta ini dijumpai di seluruh BUMDes (100\%) yang menjadi sasaran penelitian. Hal ini menunjukkan terjadinya defisit peranan stakeholders. Untuk itu, mekanisme pengelolaan BUMDes perlu diarahkan menuju optimalisasi peran banyak pihak atau stakeholders melalui pendekatan governance yang memungkinkan banyak kelompok dan kepentingan yang terlibat secara langsung dalam perumusan dan pelaksanaan kebijakan publik (Klijn \& Koppenjan, 2015). Melalui pendekatan ini menekankan pula pentingnya keterlibatan banyak stakeholders yang dimaksudkan untuk mewakili publik, untuk berdebat sebagai legitimasi proses musyawarah, setiap anggota harus memposisikan forum di luar kepentingan partisan (O'Doherty, 2017). Masyarakat desa dengan ciri gemeinschaft pada dasarnya telah memiliki potensi kebersamaan dalam kehidupannya. Untuk itu, dalam memenuhi potensi demokratis di masyarakat desa, pemerintah lokal perlu mendorong konektivitas demokratis dan konektivitas politik yang lebih besar antara forum partisipatif dan ruang publik yang lebih luas (Leroux, 2015; Moore, 2010; Ngo \& O'Cass, 2013). Melalui pendekatan ini diharapkan keterlibatan segenap stakeholders dapat meningkatkan kinerja BUMDes dalam pengelolaan kekayaan dan potensi publik masyarakat desa.

BUMDes dibentuk tidak hanya dengan semangat reinventing government dalam pengelolaan potensi desa. Namun, internalisasi semangat reinventing government tersebut tidak serta-merta membawa BUMDes pada model bisnis Profit Maximizing Businesses. BUMDes memang merupakan badan usaha yang 
profit oriented, namun sekaligus social oriented. Hal ini terjadi karena BUMDes tidak bisa dilepaskan dari akar budaya dan ciri sosial kemasyarakatan Indonesia pada umumnya. Proposisi nilai dalam BUMDes meliputi masyarakat desa dan stakeholers, di samping itu dalam model ini yang dituju bukan hanya keuntungan secara ekonomis, melainkan keuntungan secara sosial dan lingkungan. Pengelolaan aset dan potensi ekonomi desa yang semula dikelola oleh pemerintah desa bergeser dari model birokratis pemerintah desa ke model badan usaha publik yang profit oriented, namun tidak murni profit oriented karena tetap memperhatikan sisi social profit bagi masyarakat desa. Pola pengelolaan BUMDes ini merupakan perwujudan integrasi organisasi sektor swasta dan mekanisme pasar ke dalam proses pemerintahan dan penyediaan pelayanan publik, yang telah menjadi tren dalam penyelenggaraan administrasi publik (Newman and Gaffney, 2002). Kerjasama pemerintah-bisnis itu sendiri dapat membantu mengidentifikasi solusi bagi masalah kebijakan yang kompleks dan memperbaiki keberhasilan implementasi kebijakan (Kim and Darnall, 2016). Berdasarkan hasil pengamatan dan wawancara mendalam dengan informan kunci pada seluruh BUMDes sasaran penelitian, dijumpai fakta $90 \%$ menunjukkan bahwa perusahaan milik lokal lebih cenderung menghasilkan tingkat keterlibatan publik yang lebih tinggi dan hal itu penting penting untuk menopang kapasitas pemecahan masalah dalam masyarakat perdesaan (Clark and Record, 2017).

Sabatier (2017) mengemukakan bahwa selain tantangan inovasi model bisnis yang biasa, model bisnis sosial harus mempertimbangkan semua pemangku kepentingan dan menentukan keuntungan sosial yang diharapkan. Hasil penelitian telah menunjukkan bahwa
100\% BUMDes yang menjadi sasaran penelitian telah mempertimbangkan keterlibatan seluruh pemangku kepentingan khususnya masyarakat desa melalui forum-forum diskursus dan musyawarah.

Hasil pengamatan juga sejalan temuan Hosseini, et.al (2012) dalam perkembangan badan usaha desa di Iran. Menunjukkan bahwa usaha kecil pedesaan memegang berperanan penting dalam menciptakan peluang lapangan kerja dan menghasilkan produk bernilai tambah di sektor-sektor tertentu seperti pertanian. Namun, tantangan utama bagi perusahaan desa ini adalah kurangnya keberlanjutan. Dalam pandangan Hosseini, et.al (2012) inovasi dan kerjasama antar stakeholders merupakan faktor kunci keberlanjutan usaha kecil pedesaan. Jika keberadaan inovasi dan kerjasama tidak diperhatikan, maka tidak ada keber-lanjutan bagi badan usaha pedesaan. Smith dan McColl (2016) mengemukakan bahwa perbedaan antara aktivitas bisnis di pedesaan dan perkotaan bukanlah hal baru, komparator yang jelas adalah ukuran seperti arsitektur sosial, ketersediaan sumber daya dan aksesibilitas. Ia beranggapan bahwa perbedaan utama antara pengelolaan sosial perusahaan pedesaan dan perkotaan jarak jauh sangat bernuansa oleh tingkat migrasi di lokasi pedesaan dan perkotaan, kepemimpinan dan kebutuhan masyarakat dan oleh karena itu memerlukan konteks kebijakan yang relevan. Meskipun perkembangan badan usaha desa terlihat baik, namun Chen, et.al (2013) mengungkapkan bahwa BUMDes sejauh ini dikelola dengan pola kombinasi peranan antara pemerintah dan kekuatan pasar. Oleh karena itu, sifat hibrida dari struktur organisasi dan kepemilikan tersebut membuat perubahan dalam badan usaha desa masih banyak dilakukan secara top-down. 


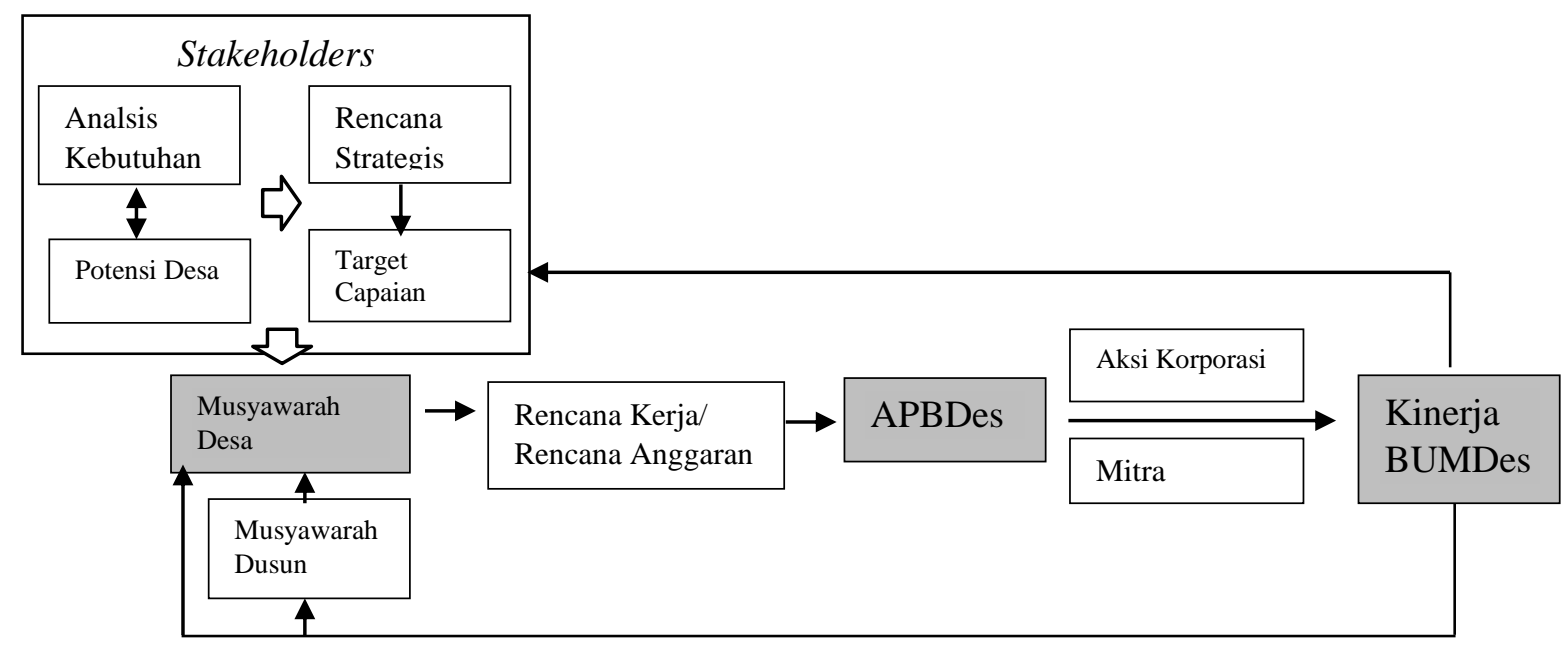

Gambar 2.

Model Governance dalam Pengelolaan BUMDes dalam Optimalisasi Kinerja

Gambar 2 di atas adalah model yang menggambarkan kondisi ideal pengelolaan BUMDes dengan menggunakan pendekatan governance terkait dengan pola pengelolaan BUMDes, khususnya di Kabupaten Banyumas. Model Governance dalam Pengelolaan BUMDes dalam Optimalisasi Kinerja merupakan suatu model rekomendasi yang dikembangkan berdasarkan hasil analisis dan pengembangan dari model existing pengelolaan BUMDes yang dimuat pada Gambar 1.

Berdasarkan Gambar 2 tentang model governance dalam pengelolaan BUMDes dalam optimalisasi kinerja dapat ditunjukkan bahwa dalam mengatasi kekosongan analisis kebutuhan dan potensi desa, maka diperlukan peranan stakeholders untuk mendorong dimuatnya kebutuhan dan potensi desa sebagai dasar penyususnan target capaian kinerja dari BUMDes. Melalui pendekatan public governance, para stakeholders saling berinteraksi dengan tujuan menemukan arah kerja dan pengembangan BUMDes yang berbasis pada analisis kebutuhan dan potensi desa (Bovaird \& Loffer, 2009). Stakeholders tersebut, antara lain: adalah unsur golongan dalam masyarakat, organisasi masyarakat, lembaga desa dan organisasi lainnya yang terkait dengan penyelenggaraan BUMDes. Mereka saling berinteraksi dalam pengelolaan organisasi publik untuk memenuhi berbagai kepentingan dan kebutuhan masyarakat desa. Melalui manajemen publik yang berorientasi pada pendekatan governance, maka rancangan model diarahkan untuk dapat menerapkan pentingnya mencapai nilai-nilai yang tidak hanya berkaitan dengan efisiensi, efetivitas, akan tetapi juga responsif dalam penyelenggaraan BUMDes.

\section{KESIMPULAN}

Berdasarkan hasil penelitian dan pembahasan, dapat disimpulkan bahwa pengelolaan BUMDes di Kabupaten Banyumas sebagaimana digambarkan dalam model eksisting menjukkan masih kuatnya dominasi unsur pemerintahan desa, khususnya dalam proses pengambilan keputusan strategis pada pengelolaan BUMDes. Sementara itu, dapat disimpulkan pula bahwa dibutuhkan optimalisasi peran stakeholders melalui pendekatan governance sebagaimana digambarkan pada model governansi publik dalam pengelolaan BUMDes di 
Kabupaten Banyumas. Berdasarkan pandang dan spektrum tentang potensi dan penelitian ini dapat disimpulkan perbedaan permasalahan kebutuhan desa. Dengan mendasar antara kondisi exisiting demikian, kondisi kebutuhan dan potensi pengelolaan BUMDes dan kondisi yang desa dapat lebih tergambarkan dengan direkomendasikan, berdasarkan nasis teori jelas. Dengan tergambarkannya kondisi governance. Dimana, keterlibatan segenap kebutuhan dan potensi desa, maka arah stakeholders dalam pengelolaan kekayaan publik masyarakat desa perlu dioptimalkan dan semakin meningkat. Dengan meningkatnya keterlibatan segenap stakeholders, maka dapat membuka cara pengembangan BUMDes menjadi jelas dan terukur yang pada giliranya dapat meningkatkan kinerja BUMDes dalam mengelola kebutuhan dan potensi desa. 


\section{DAFTAR PUSTAKA}

Bovaird, T., Loeffler, E., \& Martin, J. 2003. From corporate governance to local govrenance: Stakeholderdriven community score-cards for uk local agencies? International Journal of Public Administration, 26(8-9), 1035-1058. https://doi.org /10.1081/PAD-120019359

Cairney, P., \& Cairney, P. 2016. The Advocacy Coalition Framework. In Understanding Public Policy (pp. 200-219). https://doi.org/10.1007/ 978-0-230-35699-3_10

Chen, W., Woods, A., \& Singh, S. 2013. Organisational change and development of reformed Chinese township and village enterprises. Journal of Organizational Change Management, 26(2), 353-369. https://doi.org/10.1108/0953481131 1328399

Chygryn, O., Petrushenko, Y., Vysochyna, A., \& Vorontsova, A. 2018. Assessment of fiscal decentralization influence on social and economic development. Montenegrin Journal of Economics, 14(4), 69-84. https://doi.org/10.14254 /1800-5845/2018.14-4.5

Clark, Jill K. \& Matthew Record. 2017. "Local Capitalism and Civic Engagement: The Potential of Locally Facing Firms". Public Administration Review, 00(00): 113.

Creswell, John, 2013. Desain Penelitian, Pendekatan Kualitatif dan Kuantitatif terjemahan Angkatan III \& IV KIK-UI. KIK Press. Jakarta.

Daly, Peter. 2017. "Business apprenticeship: a viable business model in management education", Journal of Management Development. 36(6): 1-7.

Dunleavy, P., H. Margetts, S. Bastow \& J. Tinkler. 2006. "New public management is dead: Long live digital-era governance". Journal of Public Administration Research and Theory, 1:467-494.

Girotra, Karan \& Serguei Netessine. 2014. "Four Paths to Business Model Innovation". Harvard Business Review, July-August: 98-103.

Grimmelikhuijsen, S. G., \& Feeney, M. K. 2017. Developing and Testing an Integrative Framework for Open Government Adoption in Local Governments. Public Administration Review, 77(4), 579-590. https://doi.org/10.1111/puar.12689

Hahm, Sung Deuk \& Kwangho Jung. 2013. "Shaping Public Corporation Leadership in a Turbulent Environment". Public Administration Review, 73(1): 178-187.

Henry, Colette \& Gerard McElwee. 2014. "Defining and Conceptualising Rural Enterprise". Contemporary Issues in Entrepreneurship Research, 4: 1-8

Hosseini, Seyed Jamal F., Gerard McElwee, Shohreh Soltani, David J Smith. 2012. "The innovation performance of small rural enterprises and cooperatives in Tehran province, Iran". Local Economy, 27(2): 183-192.

Kavadias, Stelios, Kostas Ladas \& Christoph Loch. 2016. "The Transformative Business Model: how to tell if you have one". Harvard Business Review, October: 91-98.

Kim, Younsung \& Nicole Darnall. 2016. "Business as a Collaborative Partner: Understanding Firms' Sociopolitical Support for Policy Formation". Public Administration Review, 76(2):326-337.

Klijn, E. H., \& Koppenjan, J. 2015. Governance networks in the public sector. In Governance Networks in 
the Public Sector. https://doi.org/ 10.4324/9781315887098

Kurniasih, D., \& Israwan Setyoko, P. 2019. Public Governance Capacity In The Accountability Of VillageOwned Enterprise Manage-ment In Indonesia. Journal Sampurasun: Interdisciplinary Studies for Cultural Heritage, 5(2), 67-79. https://doi.org/10.23969/sampurasu n.v5i2.1745

Kurniasih, D., Setyoko, P. I., \& Imron, M. 2017. Problems of Public Accountability in Village Government Business Management (Study on Village Business Enterprises in Banyumas, Indonesia). Journal of Public Administration and Governance, 7(4), 147. https://doi.org/10.5296 /jpag.v7i4.11850

Kurniasih, D., \& Wijaya, S. S. 2017. Kegagalan Bisnis Pemerintah Desa: Studi Tentang Relasi BisnisPemerintah pada Pengelolaan Badan Usaha Milik Desa di Kabupaten Banyumas. JPSI (Journal of Public Sector Innovations), $\quad$ (2), 66. https://doi.org/10.26740/jpsi.v1n2.p 66-72

Leroux, K. 2015. Paternalistic or Participatory Governance? Examining Opportunities Social for Client Participation in Nonprofit. Public Administration Review, 69(3), 504-517.

Maab, M. H., Wijaya, S. S., Atika, Z. R., \& Kurniasih, D. 2018. Rethinking Model Bisnis Pemerintah Desa: Kasus Pada Badan Usaha Milik Desa Di Kabupaten Banyumas, Indonesia. Jurnal Litbang Provinsi Jawa Tengah, $16 \quad$ (1). https://doi.org/10.36762/litbangjate ng.v16i1.754

Matheus, R., \& Ribeiro, M. M. (2009).
Models for citizen engagement in Latin American - Case studies of public digital budgeting. $A C M$ International Conference Proceeding Series, 109-116. https://doi.org/10.1145/1693042.16 93065

Moore, A. 2010. Public bioethics and deliberative democracy. Political Studies, 58(4), 715-730. https://doi.org/10.1111/j.14679248.2010.00836.x

Milles, B Mathew \& Huberman A Michael \& Saldana Johnny, 2014, Qualitative Data Analysis, A Methode Sourcebook, USA: Sage Publication. Inc.

Moore, A. 2010. Public bioethics and deliberative democracy. Political Studies, 58(4), 715-730. https://doi.org/10.1111/j.14679248.2010.00836.x

Morçöl, G., \& Wolf, J. F. 2010. Understanding Business Improvement Districts: A New Governance Framework. Public Administration Review, 70(6), 906913. https://doi.org/10.1111/j.15406210.2010.02222.x

Najmaei, Arash \& Zahra Sadeghinejad. 2016. "Toward a Theory of Business Models and Business Modeling in Public Entrepreneurship" In New Perspectives on Research, Policy \& Practice in Public Entrepreneurship. Emerald Group Publishing Ltd, 6: 77-102.

Newman, Meredith A. \& Michael J. Gaffney. 2002. "A Clash of Values: Public Ethics and the Business of Government". International Review of Public Administration, 7(1): 1727.

Ngo, L. V., \& O’Cass, A. 2013. Innovation and business success: The mediating role of customer 
participation. Journal of Business Research, 66(8), 1134-1142. https://doi.org/10.1016/j.jbusres.20 12.03.009

O'Doherty, K. C. 2017. Deliberative public opinion. History of the Human Sciences, 30(4), 124-145. https://doi.org/10.1177/0952695117 722718

Osborne, D \& Gaebler, T. 1997. Reinventing Government: How The Entepreneurial Spirit is Transforming the public sector. Harvard University Press.

Ranerup, Agneta, Helle Zinner Henriksen \& Jonas Hedman. 2016. "An analysis of business models in Public Service Platforms". Government Information Quarterly, 33(1): 6-14.

Sabatier, V., Medah, I., Augsdorfer, P., \& Maduekwe, A. 2017. Social business model design and implementation in developing countries: Learning from an affordable medicine developed in Burkina Faso. Journal of Management Development, 36(1), 48-57. https://doi.org/10.1108/ JMD-03-2015-0041
Smith, Anne MJ. \& Julie McColl. 2016. "Contextual influences on social enterprise management in rural and urban communities". Local Economy, 31(5): 572-588.

Steinerowski, Artur A. \& Izabella Steinerowska-Streb. 2012. "Can social enterprise contribute to creating sustainable rural communities? Using the lens of structuration theory to analyse the emergence of rural social enterprise". Local Economy, 27(2): 167-182

Velu, Chander, Mahima Khanna. 2013. "Business model innovation in India", Journal of Indian Business Research, 5(3): 156-170.

Wang, Juan. 2005. "Going Beyond Township and Village Enterprises in Rural China". Journal of Contemporary China, 14(42): 177187.

Yunus, M., Moingeon, B., \& LehmannOrtega, L. 2010. Building social business models: Lessons from the grameen experience. Long Range Planning, 43(2-3), 308-325. https://doi.org/10.1016/j.lrp.2009.1 2.005 